\title{
Kecemasan Ditinjau dari Penerimaan Diri dan Dukungan Sosial pada Remaja Penyandang Tunanetra
}

\author{
Received March 8, 2020 | Accepted June 20, 2020
}

\author{
Liedya Liedya* \\ liedya98@gmail.com
}

Sri Mariati Br Tarigan

srimariatibrtarigan@gmail.com

\author{
Elbert Justio \\ bertjustio@gmail.com
}

Tiffany Novina

novihuang1124@gmail.com

\section{Winida Marpaung}

winida.marpaung@gmail.com

Universitas Prima Indonesia Medan

\begin{abstract}
Blind people limitations affect their movement development, learning ability, and psychological development because the difficulty of understanding and accepting the surrounding environment conditions. This study aims to examine the relationship between self-acceptance and social support with anxiety. The hypothesis of this research was there is a relationship between self-acceptance and social support with anxiety. Subjects in this research were 80 blind adolescents in Pertuni Medan Foundation. Data analysis used is Multiple Linear Analysis through the help of SPSS 25 for Windows. Data analysis results showed that there is no relationship between self-acceptance and social support with anxiety. Keywords: anxiety, self-acceptance, social support
\end{abstract}

\begin{abstract}
Abstrak. Keterbatasan penyandang tunanetra mempengaruhi perkembangan gerak, kemampuan belajar, dan perkembangan psikologis mereka karena sulitnya memahami dan menerima kondisi lingkungan sekitar. Penelitian ini bertujuan untuk melihat hubungan antara penerimaan diri dan dukungan sosial dengan kecemasan. Hipotesis penelitian ini adalah ada hubungan antara penerimaan diri dan dukungan sosial dengan kecemasan. Subjek dalam penelitian ini adalah 80 remaja penyandang tunanetra di Yayasan Pertuni Medan. Analisis data yang digunakan adalah Analisis Regresi Linear Berganda melalui bantuan SPSS 25 for Windows. Hasil analisis data menunjukkan bahwa tidak ada hubungan antara penerimaan diri dan dukungan sosial dengan kecemasan.
\end{abstract}

Kata kunci: kecemasan, penerimaan diri, dukungan sosial

\section{PENDAHULUAN}

Kesehatan menjadi kebutuhan manusia yang mendasar. Berbagai cara dilakukan agar memperoleh tubuh yang sehat. Tubuh sehat diindentikkan dengan kondisi fisiologis dan psikologis yang berkembang dengan baik. Semua fase perkembangan dari masa anakanak hingga usia lanjut memerlukan kondisi diri yang sehat agar secara optimal dan mampu melakukan tanggung jawab untuk memenuhi kebutuhan disemua aspek kehidupan. Salah satu masa perkembangan terpenting dan berkaitan erat dengan masa produktif yakni usia remaja.

Sayangnya, sebagian remaja harus mengalami kesulitan karena terhalang oleh keterbatasan yang mereka miliki. Salah satunya, remaja dengan masalah keterhambatan kemampuan diri (disability). Orang yang memiliki kelainan pada fisik ataupun non-fisik disebut sebagai penyandang disabilitas. Salah satu disabilitas yang banyak ditemui di 
Indonesia adalah tunanetra. Sensus Penduduk 2010 menunjukkan hasil riset bahwa penyandang tunanerta memiliki persentasi tertinggi sebesar 3,05\%, sedangkan

penyandang disabilitas yang lain hanya sekitar 1-2\%. Berdasarkan data Program Perlindungan dan Layanan Sosial (PPLS) tahun 2012, penyandang tunanetra berjumlah 142.860 jiwa dari 3.838.985 jiwa penyandang disabilitas yang ada di Indonesia (Kementrian Kesehatan RI, 2014).

Penyandang tunanetra memiliki persepsi yang berbeda terhadap dunia dibandingkan dengan orang yang memiliki penglihatan normal. Persepsi mereka akan mempengaruhi proses perkembangan pribadi individu tersebut seperti yang dialami remaja penyandang tunanetra yang berada di Yayasan Pertuni Medan. Hal tersebut terungkap saat peneliti melakukan wawancara dan observasi. Peneliti melakukan wawancara terhadap tiga remaja penyandang tunanetra, yaitu $\mathrm{G}, \mathrm{R}$, dan W.

Pertama, G yang merupakan seorang penyandang low vision, mengatakan bahwa dampak negatif yang diperoleh dari keterhambatan fisik yang dialaminya yaitu sulit mempercayai orang lain dan juga sulit mendapat bantuan karena dianggap pura-pura buta karena mengenakan kacamata yang dapat membantu penglihatan penyandang low vision. Oleh karena itu, G menjadi tidak pernah mengenakan kacamata lagi dan juga tidak pernah menggunakan tongkat agar dapat terhindar dari anggapan tersebut. Padahal penggunaan kacamata dan tongkat dapat lebih memudahkan aktivitasnya. $G$ juga merasa khawatir untuk bersosialisasi karena takut tidak diterima oleh orang lain sehingga malu dan tidak mau menunjukan jati dirinya.

Kedua, $\mathrm{R}$ mengungkapkan dampak negatif dari keterhambatan fisiknya yakni merasa sulit untuk bepergian keluar tanpa ada orang yang dipercayai. $\mathrm{R}$ juga merasa khawatir akan masa depannya. Ketiga, W menyatakan merasa takut akan ditipu oleh orang lain seperti diberikan uang kembalian dengan jumlah yang salah saat berbelanja. Peneliti juga melakukan observasi terhadap para subjek. Saat proses rapport, peneliti mengajak para subjek untuk berkenalan dan berusaha untuk mendekatkan diri dengan para subjek. Ada subjek yang cukup terbuka kepada peneliti dan bahkan mengajak peneliti untuk berbicara terlebih dahulu. Akan tetapi, ada juga subjek yang hanya menjawab pertanyaan peneliti dengan singkat dan dengan suara yang kecil. Bahkan ada subjek yang terlihat gugup, tidak menjawab ketika ditanya oleh peneliti, dan hanya menggoyang-goyangkan kakinya. Ada juga subjek yang langsung pergi ke kamarnya setelah peneliti datang. Saat proses wawancara sedang berlangsung, ada subjek yang menjawab dengan rinci dan mau menjelaskan jawabannya ketika diminta oleh peneliti. Namun, ada juga subjek yang menjawab dengan suara yang kecil. Subjek juga kebanyakan menjawab dengan singkat seperti menjawab iya ataupun tidak. Bahkan subjek juga enggan untuk menjawab saat diwawancarai dengan pertanyaan-pertanyaan tertentu. Hasil wawancara dan observasi ini menunjukkan bahwa para subjek menunjukkan gejala-gejala kecemasan sama seperti beberapa gejala kecemasan yang dipaparkan oleh Clark \& Beck (2011), yaitu gugup, gelisah, diam (ketika diajak berbicara), menghindari situasi yang membuatnya merasa tidak nyaman, takut dinilai buruk oleh orang lain, dan kewaspadaan berlebih terhadap sesuatu.

Freud (dalam Semiun, 2010) mengatakan bahwa kecemasan merupakan suatu keadaan muncul perasaan tidak nyaman yang diikuti dengan munculnya sensasi fisik yang memperingatkan orang tersebut tentang kemungkinan terjadinya suatu peristiwa yang tidak menyenangkan. Kecemasan tidak hadir dari jaringan dalam tubuh melainkan dari luar dan akan mendorong manusia melakukan sesuatu untuk mengurangi rasa kecemasannya. Seseorang akan mengalami sakit secara emosional apabila kecemasan 
yang dimilikinya meningkat sampai Ia merasa sulit untuk melanjutkan hidupnya. Dengan memberikan dukungan sosial dapat membantu seseorang untuk mereduksi kecemasan yang dimilikinya.

Penelitian terdahulu mengungkapkan hal yang sama terkait masalah dukungan sosial dengan kecemasan. Utomo (2018) menemukan bahwa terdapat hubungan negatif antara dukungan sosial dengan kecemasan pada ibu hamil di Rumah Sakit Bersalin

Pemerintah Kota Malang. Penelitian yang dilakukan oleh Syafitri (2015) juga menunjukkan bahwa terdapat hubungan negatif antara dukungan sosial dengan kecemasan pada karyawan dalam menghadapi masa pensiun. Hal ini menunjukkan bahwa ketika seseorang menerima dukungan sosial dari orang-orang sekitarnya maka akan membuat individu tersebut merasa tenang tanpa ada rasa cemas dalam hidupnya. Sebaliknya ketika dukungan sosial yang diterima sedikit atau bahkan tidak ada maka akan memicu munculnya kecemasan yang tinggi. Menurut Jacob (dalam Orford, 2011), dukungan sosial merupakan suatu perilaku yang dapat memberikan rasa nyaman, membuat seseorang merasa dihormati, dihargai, dicintai, dan diberikan perhatian serta keamanan oleh orang lain.

Selain dukungan sosial, penerimaan diri juga memberikan pengaruh terhadap muncul atau tidaknya kecemasan. Penelitian yang dilakukan oleh Wulan \& Ediati (2019) terhadap 98 orang warga binaan permasyarakatan wanita kasus narkotika di Kalimantan Timur menunjukkan adanya hubungan negatif antara penerimaan diri dengan kecemasan. Hasil yang sama juga ditunjukkan oleh penelitian yang dilakukan Wulandari \& Lestari (2018) yang menunjukkan adanya hubungan negatif antara penerimaan diri dengan kecemasan pada Pegawai Negeri Sipil (PNS) di Kabupaten Bandung dalam menghadapi masa pensiun. Hal ini berarti jika penerimaan diri seseorang itu baik maka akan membuat orang tersebut memiliki tingkat kecemasan yang rendah. Akan tetapi, apabila seseorang tidak memiliki penerimaan diri yang baik maka akan berakibat pada meningkatnya kecemasan yang dimiliki.

Sheerer (dalam Nur, 2014) mengatakan bahwa penerimaan diri adalah penilaian secara objektif yang dilakukan seseorang mengenai diri dan keadaannya. Seseorang yang menerima dirinya tidak hanya akan menerima kelebihannya saja, tetapi juga dapat menerima kelemahan dalam dirinya. Seseorang dapat dikatakan telah menerima dirinya apabila telah menyadari, memahami, dan menerima dirinya dengan apa adanya yang diikuti dengan kemauan serta kemampuan untuk dapat terus mengembangkan dirinya sehingga dapat menjalani hidup dengan baik dan penuh tanggung jawab.

Penelitian ini bertujuan memaparkan remaja yang mengalami keterbatasan penglihatan mampu menggunakan dukungan sosial dan penerimaan diri untuk mengurangi tingkat kecemasan dalam dirinya, khususnya pada remaja penyandang tunanetra di Yayasan Pertuni Medan. Hipotesis yang diajukan dalam penelitian ini yakni adanya hubungan negatif antara penerimaan diri dan dukungan sosial dengan kecemasan.

\section{METODE}

Penelitian ini merupakan penelitian dengan pendekatan kuantitatif dengan jenis penelitian korelasional. Variabel dalam penelitian ini yakni penerimaan diri dan dukungan sosial sebagai variabel independent dan kecemasan sebagai variabel dependent.

Terdapat 80 remaja perempuan dan laki-laki penyandang tunanetra, berusia 12-21 tahun yang berada di Yayasan Pertuni Medan yang dipilih sebagai subjek penelitian dengan menggunakan teknik total sampling. Dengan menggunakan teknik total sampling, semua populasi dijadikan sebagai sampel penelitian (Sugiyono, 2017). 
Penelitian ini menggunakan skala likert sebagai alat dalam pengumpulan data. Peneliti melakukan pengumpulan data dengan menggunakan bantuan software NVDA (Non Visual Desktop Access) yang merupakan software pembaca layar. Saat pengumpulan data, peneliti menyediakan laptop yang sudah terdapat software NVDA beserta softcopy skala penelitian kepada para subjek. Subjek akan mendengarkan item skala dengan bantuan software NVDA dan kemudian menuliskan jawabannya di kertas dalam bentuk braille. Skala yang digunakan dalam penelitian ini adalah skala kecemasan, skala penerimaan diri, dan skala dukungan sosial.

Skala kecemasan terdiri dari 14 item yang diadaptasi oleh peneliti dari Hamilton Anxiety Rating Scale. Sebelum melakukan try out kepada subjek penelitian, dilakukan expert judgement pada skala. Expert judgement pada skala telah dilakukan oleh psikolog, aktivis tunanetra, dan penyandang tunanetra. Dari hasil uji validitas, diperoleh bahwa semua item valid dengan daya diskriminasi item 0.484-0.730 $>0.30$. Dari hasil uji reliabilitas, diperoleh koefisien reliabilitas sebesar 0.913 .

Skala penerimaan diri terdiri dari 42 item yang disusun berdasarkan aspekaspek penerimaan diri menurut Supratiknya (2016), antara lain: (a) Kerelaan untuk membuka atau mengungkapkan aneka pikiran, perasaan, dan reaksi kita kepada orang lain; (b) Kesehatan psikologis; (c) Penerimaan terhadap orang lain. Dari hasil uji validitas, diperoleh 30 item yang valid dengan daya diskriminasi item 0.319-0.724 > 0.30. Dari hasil uji reliabilitas, diperoleh koefisien reliabilitas sebesar 0.932 .

Skala dukungan sosial terdiri dari 42 item yang disusun berdasarkan aspek-aspek yang diungkapkan oleh Sarafino \& Smith (2011), yaitu emotional or esteem, informational, dan tangible. Dari hasil uji validitas, diperoleh 40 item yang valid dengan daya diskriminasi item 0.329-0.808 > 0.30. Dari hasil uji reliabilitas, diperoleh koefisien reliabilitas sebesar 0.965 .

Penelitian ini menggunakan try out terpakai yang disebabkan oleh keterbatasan jumlah subjek penelitian yang merupakan penyandang tunanetra sehingga pengambilan data hanya dilakukan satu kali. Teknik analisis data yang digunakan dalam penelitian ini adalah analisis regresi linier berganda menggunakan bantuan SPSS versi 25 for Windows.

\section{HASIL}

Uji asumsi yang digunakan dalam penelitian ini adalah uji normalitas, uji multikolinearitas, uji heteroskedastisitas, dan uji autokorelasi.

Tabel 1 Hasil Uji Normalitas

\begin{tabular}{cccccc}
\hline Variabel & SD & KS-Z & Sig. & P & Keterangan \\
\hline Kecemasan & 10.471 & 0.080 & 0.200 & $\mathrm{p}>0.05$ & Sebaran normal \\
Penerimaan Diri & 11.032 & 0.129 & 0.110 & $\mathrm{p}>0.05$ & Sebaran normal \\
Dukungan Sosial & 10.792 & 0.107 & 0.138 & $\mathrm{p}>0.05$ & Sebaran normal \\
\hline
\end{tabular}

Uji normalitas menggunakan uji One Sample Kolmogorov-Smirnov. Data dikatakan terdistribusi secara normal jika p>0.05 (Priyatno, 2011). Hasil uji normalitas menunjukkan signifikansi pada variabel kecemasan $(\mathrm{p}=0.200)$, variabel penerimaan diri $(\mathrm{p}=0.110)$, dan variabel dukungan sosial $(\mathrm{p}=0.138)$ lebih besar dari 0.05 yang berarti ketiga variabel tersebut memiliki data yang terdistribusi secara normal. 
Tabel 2 Hasil Uji Multikolinearitas

\begin{tabular}{ccc}
\hline \multirow{2}{*}{ Model } & \multicolumn{2}{c}{ Collinearity Statistics } \\
\cline { 2 - 3 } & Tolerance & VIF \\
\hline Penerimaan Diri & 0.274 & 3.653 \\
Dukungan Sosial & 0.274 & 3.653 \\
\hline
\end{tabular}

Dalam uji multikolinearitas, jika nilai VIF $<10$, berarti tidak terjadi multikolinearitas. Sedangkan jika nilai VIF > 10, berarti terjadi multikolinearitas (Priyatno, 2011). Berdasarkan tabel 2, nilai VIF dari variabel penerimaan diri adalah 3.653 dan nilai VIF dari variabel dukungan sosial adalah 3.653. Masing-masing nilai VIF tidak lebih besar dari 10 maka tidak terdapat gejala multikolinearitas yang berat. Hal tersebut membuktikan bahwa tidak terjadi korelasi antara variabel bebas yang signifikan.

Tabel 3 Hasil Uji Heteroskedastisitas

\begin{tabular}{cccc}
\hline Model & $\begin{array}{c}\text { Sig }(1- \\
\text { tailed })\end{array}$ & $\begin{array}{c}\text { Nilai } \\
\text { Statistik }\end{array}$ & Keterangan \\
\hline Penerimaan Diri & 0.303 & $\mathrm{P}>0.05$ & Tidak terjadi heteroskedastisitas \\
\hline Dukungan Sosial & 0.448 & $\mathrm{P}>0.05$ & Tidak terjadi heteroskedastisitas \\
\hline
\end{tabular}

Berdasarkan tabel 3, nilai signifikansi dari penerimaan diri $(p=0.303)$ dan dukungan sosial $(\mathrm{p}=0.448)$ lebih besar dari 0.05 yang berarti tidak terjadi masalah heteroskedastisitas.

Tabel 4 Hasil Uji Autokorelasi

\begin{tabular}{ccc}
\hline Durbin-Watson & Nilai Statistik & Keterangan \\
\hline 1.865 & $\mathrm{du}<\mathrm{dw}<4-\mathrm{du}$ & Asumsi non-autokorelasi \\
\hline
\end{tabular}

Berdasarkan tabel 4, nilai dari uji statistik Durbin-Watson adalah 1.865. Dengan kata lain, tidak terjadi gejala autokorelasi pada kesalahan pengganggu dikarenakan nilai statistik Durbin-Watson adalah du (1.688) < dw (1.865) < $4-\mathrm{du}(2.312)$, maka asumsi non-autokorelasi terpenuhi.

Tabel 5 Hasil Analisis Regresi Berganda

\begin{tabular}{ccc}
\hline Model & F & Sig. \\
\hline Regression & 1.823 & 0.168 \\
\hline
\end{tabular}

Dilakukan uji F untuk menguji pengaruh variabel independent secara bersama-sama terhadap variabel dependent (Priyatno, 2011). Tahap-tahap uji F (Priyatno, 2011), antara lain: (1) Menentukan Ho, yaitu penerimaan diri dan dukungan sosial tidak berpengaruh terhadap kecemasan; (2) Ditentukan signifikansi sebesar 0.05; (3) Dari hasil regresi di atas, ditentukan bahwa F hitung memiliki nilai sebesar 1.823; (4) Tentukan nilai Df1 dan Df2 untuk menentukan nilai F tabel menggunakan rumus Df1 = Jumlah Variabel - 1 (3 $1=2)$ dan Df2 = Jumlah Subjek - Jumlah Variabel Independen $-1(80-2-1=77)$. Dari hasil peritungan tersebut, ditentukan bahwa $\mathrm{F}$ tabel sebesar 3.115 berdasarkan Tabel $\mathrm{F}$ Statistics (Signifikansi 0.05); (5) Dilakukan pengujian Ho dengan kriteria pengujian jika F hitung $<=$ F tabel maka Ho diterima, sedangkan jika F hitung $>$ F tabel maka Ho ditolak. Karena $\mathrm{F}$ hitung $<=\mathrm{F}$ tabel $(1.823<=3.115)$ maka dapat disimpulkan bahwa Ho 
diterima, artinya penerimaan diri dan dukungan sosial tidak berpengaruh terhadap kecemasan.

Tabel F Statistics (Signifikansi 0.05)

\begin{tabular}{ccc}
\hline \multirow{2}{*}{ Df2 } & \multicolumn{2}{c}{ Df1 } \\
\cline { 2 - 3 } & $\mathbf{1}$ & $\mathbf{2}$ \\
\hline $\mathbf{7 6}$ & 3.967 & 3.117 \\
\hline $\mathbf{7 7}$ & 3.965 & 3.115 \\
\hline
\end{tabular}

Sumber: Function Statistical Microsoft Excel (Priyatno, 2011)

\section{DISKUSI}

Hasil penelitian pada 80 remaja tunanetra Yayasan Pertuni Medan yang menjadi subjek penelitian menunjukkan bahwa hipotesis yang menyatakan bahwa adanya hubungan antara penerimaan diri dan dukungan sosial terhadap kecemasan ditolak. Diperoleh hasil bahwa penerimaan diri dan dukungan sosial tidak berpengaruh terhadap kecemasan.

Hasil penelitian ini berbeda dengan penelitian yang dilakukan oleh Hermawan (2017) yang menunjukkan bahwa adanya hubungan negatif antara penerimaan diri dengan kecemasan pada mahasiswi Stikes Bethesda Yakkum. Kecemasan tidak dipengaruhi oleh penerimaan diri disebabkan karena beberapa alasan, salah satunya adalah di mana penerimaan diri merupakan salah satu faktor internal yang merupakan faktor yang diperoleh dari dalam diri individu. Prihadhi (2012) mengatakan bahwa apabila seseorang pasrah dan jujur terhadap kondisinya berarti Ia dapat menerima diri dengan apa adanya. Partisipan dalam penelitian ini merupakan penyandang tunanetra yang sudah mendapatkan pendidikan dan bimbingan di asrama dan sekolah yang membuat mereka tidak menghiraukan kelemahan atau keterbatasan mereka, melainkan menerima kondisi mereka dengan cara bersyukur dan tidak menjadikan keterbatasan sebagai beban yang memicu munculnya stres bahkan kecemasan. Faktor lainnya adalah partisipan dalam penelitian ini tinggal bersama orang-orang yang memiliki keterbatasan yang sama. Kondisi ini membuat partisipan tidak menghiraukan perbedaan yang mereka miliki, melainkan mengabaikan keterbatasan yang mereka miliki sehingga tidak pernah mengalami konflik, bullying, dan lainnya.

Hasil penelitian ini juga tidak sejalan dengan penelitian yang dilakukan oleh Sekarina \& Indriana (2018) yang menunjukkan bahwa ada hubungan negatif antara dukungan sosial dengan kecemasan pada siswa kelas XII SMK Yudya Karya Magelang. Tidak adanya hubungan antara dukungan sosial dengan kecemasan ini dipengaruhi karena partisipan tidak menghiraukan dukungan sosial yang mereka akan peroleh. Partisipan tidak perlu mencari atau meminta dukungan sosial dari orang-orang di sekitar mereka, karena semua kebutuhan sudah terpenuhi selama di asrama. Para donatur juga memberi bantuan kepada para partisipan baik secara moral dan dana. Rasa nyaman dan aman membuat mereka tidak memperhitungkan beban hidup yang akan mereka alami sehingga meminimalisir munculnya kecemasan. Sarafino \& Smith (2011) menjelaskan bahwa dukungan sosial mampu memodifikasi respon seseorang terhadap sumber stres, meyakinkan seseorang dapat menyelesaikan masalahnya dengan baik sehingga mengurangi kecemasan karena sumber stres yang diterima.

Kusumaningsih (2017) dalam hasil penelitiannya mengatakan bahwa saat mengalami peristiwa yang dapat menyebabkan stres, setiap orang cenderung akan mengalami kecemasan. Sarafino \& Smith (2011) mengatakan bahwa ketika seseorang mengalami peristiwa yang menimbulkan stres, dukungan sosial yang mereka terima tidak 
selalu memberikan dampak positif, tetapi juga dapat memberikan dampak negatif. Contoh dampak negatif dari dukungan sosial, antara lain dukungan tidak sesuai dengan apa yang dibutuhkan, dukungan tidak dapat membantu, dan over protective yang membuat individu tidak mendapatkan dukungan dalam melakukan hal yang diinginkannya.

Berdasarkan penelitian yang dilakukan oleh Marni \& Yuniawati (2015), dukungan sosial merupakan salah satu faktor yang dapat mempengaruhi penerimaan diri. Penerimaan diri seseorang akan semakin baik apabila memperoleh dukungan sosial dari sekitarnya. Hal ini juga yang mempengaruhi mengapa tidak ada hubungan antara penerimaan diri dan dukungan sosial terhadap kecemasan karena dukungan sosial ternyata faktor yang mempengaruhi penerimaan diri dan kecemasan.

\section{KESIMPULAN}

Hasil penelitian menunjukkan bahwa tidak terdapat hubungan antara penerimaan diri dan dukungan sosial dengan kecemasan pada remaja tunanetra di Yayasan Pertuni Medan. Kecemasan tidak dipengaruhi oleh penerimaan diri disebabkan oleh beberapa faktor. Pertama, remaja tunanetra di Yayasan Pertuni Medan sudah memperoleh pendidikan dan bimbingan yang membuat mereka dapat menerima kondisi mereka dengan cara bersyukur dan tidak menjadikan keterbatasan sebagai beban yang memicu munculnya kecemasan. Kedua, remaja tunanetra tinggal bersama-sama di asrama. Tinggal bersama dengan orang-orang yang memiliki keterbatasan yang sama membuat mereka tidak menghiraukan perbedaan yang mereka miliki dan dapat mengabaikan keterbatasan yang mereka miliki. Kecemasan juga tidak dipengaruhi oleh dukungan sosial. Hal ini disebabkan karena remaja tunanetra di Yayasan Pertuni Medan tidak perlu mencari atau meminta dukungan sosial dari orang-orang di sekitar mereka karena semuanya dapat mereka peroleh selama di asrama. Rasa nyaman dan aman membuat mereka tidak perlu merasa cemas dalam memperhitungkan beban hidup yang akan mereka alami.

\section{SARAN}

Remaja penyandang tunanetra disarankan untuk tetap memiliki penerimaan diri dan dukungan sosial yang baik dengan melihat potensi yang ada di dalam diri. Yayasan Pertuni Medan disarankan agar dapat melatih para penyandang tunanetra agar mampu mengatasi masalahnya secara mandiri. Saran bagi peneliti selanjutnya yakni menetapkan faktor pengaruh sebagai variabel independent. Disarankan kepada peneliti selanjutnya agar mempertimbangkan beberapa faktor lain yang dapat mempengaruhi variabel dan membuat desain penelitian yang lebih matang.

\section{DAFTAR PUSTAKA}

Clark, D. A., \& Beck, A. T. (2011). Cognitive therapy of anxiety disorders. New York: The Guilford Press.

Hermawan, E. (2017). Pengaruh penerimaan diri remaja putri terhadap tingkat kecemasan akibat kegemukan pada mahasiswi prodi keperawatan stikes bethesda yakkum 2016. E-Jurnal Bimbingan Dan Konseling, 6(1), 40-52.

Kementrian Kesehatan RI. (2014). Situasi penyandang disabilitas. http://www.depkes.go.id/download.php?file=download/pusdatin/buletin/buletindis abilitas.pdf

Kusumaningsih, L. P. S. (2017). Penerimaan diri dan kecemasan terhadap status narapidana. Jurnal Psikologi Ilmiah, 9(3), 234-242. 
Marni, A., \& Yuniawati, R. (2015). Hubungan antara dukungan sosial dengan penerimaan diri pada lansia di panti wredha budhi dharma yogyakarta. Empathy, 3(1), 1-7.

Nur, H. (2014). Proceedings “integrating knowledge with science and religion." Johor: UTM.

Orford, J. (2011). Community Psychology: Theory and practice. Chichester: John Willey $\&$ Sons, Ltd.

Prihadhi, E. K. (2012). My potency. Jakarta: PT Elex Media Komputindo.

Priyatno, D. (2011). Buku saku spss. Jakarta: PT Buku Seru.

Sarafino, E. P., \& Smith, T. W. (2011). Health psychology. USA: John Wiley \& Sons, Inc.

Sekarina, D. P., \& Indriana, Y. (2018). Hubungan antara dukungan sosial orangtua dengan kecemasan menghadapi dunia kerja pada siswa kelas xii smk yudya karya magelang. Jurnal Empati, 7(1), 381-386.

Semiun, Y. (2010). Teori kepribadian dan terapi psikoanalitik freud. Yogyakarta: Penerbit Kanisius.

Sugiyono. (2017). Metode penelitian kuantitatif, kualitatif, dan $r \& d$. Bandung: Alfabeta.

Supratiknya, A. (2016). Komunikasi antar pribadi: Tinjauan psikologi. Yogyakarta: Kanisius.

Syafitri, A. (2015). Pengaruh tingkat dukungan sosial keluarga terhadap tingkat kecemasan menjelang pensiun pada karyawan perusahaan $\mathrm{x}$ di kecamatan kebomas kabupaten gresik. Jurnal Psikosains, 10(1), 25-43.

Utomo, Y. D. C. (2018). Pengaruh dukungan sosial terhadap tingkat kecemasan ibu hamil di rumah sakit bersalin pemerintah kota malang. Jurnal Psikovidya, 22(2), 197-223.

Wulan, A. P. N., \& Ediati, A. (2019). Hubungan antara penerimaan diri dengan kecemasan pada warga binaan permasyarakatan wanita kasus narkotika di kalimantan timur. Jurnal Empati, 8(1), 173-184.

Wulandari, P. D., \& Lestari, M. D. (2018). Pengaruh penerimaan diri pada kondisi pensiun dan dukungan sosial terhadap kecemasan menghadapi masa pensiun pada pegawai negeri sipil di kabupaten bandung. Jurnal Psikologi Udayana, 5(2), 311323. 